\title{
Ketogenic food pyramid for patients with refractory epilepsy: From theory to clinical practice
}

\author{
Pirâmide alimentar cetogênica para \\ pacientes com epilepsia refratária: \\ da teoria à prática clínica
}

\author{
Mariana Baldini PRUDENCIO ${ }^{1}$ \\ Patricia de Azevedo LIMA² \\ Maria Camila Pruper de FREITAS ${ }^{1}$ \\ Flávia de Conti CARTOLANO ${ }^{1}$ \\ Daniela Kawamoto MURAKAMI ${ }^{3}$ \\ Nágila Raquel Teixeira DAMASCENO 4
}

\section{A B S T R A C T}

\section{Objective}

To develop a graphical representation in the form of a food pyramid for a ketogenic diet for dietary treatment in children and adolescents with refractory epilepsy.

\section{Methods}

The pyramid was constructed based on: the estimation of energy requirements for different age groups, macronutrient distribution, food groups, and the number of servings and respective amounts of food according to the ketogenic diet. Serving sizes were based on the calculation of energy and macronutrient requirements according to age and nutritional status.

\section{Results}

The pyramid was divided into three tiers and 5 food groups (fats, proteins, type 1 vegetables, type 2 vegetables, and fruits). Four portion size lists were defined for the following age groups: 1-3 years, 4-6 years, 7-10 years, and $11-19$ years.

\footnotetext{
1 Universidade de São Paulo, Faculdade de Saúde Pública, Programa de Pós-Graduação em Nutrição em Saúde Pública. São Paulo, SP, Brasil.

2 Universidade de São Paulo, Programa de Pós-Graduação em Nutrição Humana Aplicada. São Paulo, SP, Brasil.

3 Universidade de São Paulo, Faculdade de Medicina, Instituto da Criança. São Paulo, SP, Brasil.

${ }^{4}$ Universidade de São Paulo, Faculdade de Saúde Pública, Departamento de Nutrição. Av. Dr. Arnaldo, 715, 01246-904, São Paulo, SP, Brasil. Correspondência para/Correspondence to: NRT DAMASCENO. E-mail: <nagila@usp.br>.

Support: Fundação de Amparo à Pesquisa do Estado de São Paulo (Process no 2012/20789-5 and 2012/03775-0).
} 


\section{Conclusion}

The ketogenic diet food pyramid can be used as nutritional guidance for patients undergoing this dietary therapy by illustrating the variety of foods that can be eaten during the treatment, optimizing adherence to the treatment, and guaranteeing beneficial effects on seizure control.

Keywords: Adolescent. Child. Epilepsy. Food and nutrition education. Ketogenic Diet.

\section{RE S U M O}

\section{Objetivo}

Desenvolver uma representação gráfica sob a forma de pirâmide alimentar para a dieta cetogênica destinada a crianças e adolescentes com indicação de tratamento dietético da epilepsia refratária.

\section{Métodos}

A construção foi baseada na estimativa da necessidade energética por faixa etária, na distribuição de macronutrientes, nos grupos alimentares, no número de porções e nas respectivas quantidades de alimentos a serem ofertados de forma a atender as recomendações da dieta cetogênica. O porcionamento dos alimentos foi feito baseado no cálculo da necessidade energética e na distribuição de macronutriente segundo a faixa etária e estado nutricional.

\section{Resultados}

A pirâmide foi dividida em três estratos e em cinco grupos alimentares (gorduras, proteínas, hortaliças tipo 1, hortaliças tipo 2 e frutas). Foram elaboradas quatro listas de porcionamento para as seguintes faixas etárias 1 a 3 anos, 4 a 6 anos, 7 a 10 anos e 11 a 19 anos.

\section{Conclusão}

A utilização da pirâmide alimentar da dieta cetogênica facilitará a orientação inicial dos pacientes submetidos a essa terapia nutricional, ilustrando a diversidade de alimentos que podem ser ofertados durante o tratamento e otimizando, assim, a aderência ao mesmo e a manutenção dos efeitos benéficos de controle de crises.

Palavras-chave: Adolescente. Criança. Epilepsia. Educação alimentar e nutricional. Dieta cetogênica.

\section{INTRODUCTION}

Epilepsy is a chronic neurological disorder characterized by recurrent seizures and is often accompanied by cognitive and neuropsychomotor deficits $^{1}$. It is estimated that $20 \%$ to $30 \%$ of pediatric patients have epilepsy refractory to pharmacological treatment ${ }^{2}$.

The Ketogenic Diet (KD) developed by Wilder in 1921 has been widely used as an alternative and important adjuvant pharmacological treatment of refractory epilepsy ${ }^{3}$. It is a high-fat, low-carbohydrate, moderate-protein diet ${ }^{2}$. The ratio of fat to carbohydrates and proteins can range from 2:1, 3:1 and 4:1, which refers to the ratio of grams of fat in the diet to every gram of carbohydrates and proteins ${ }^{4-6}$. According to Kossoff $\&$ Wang $^{3}$, approximately one third of patients with refractory epilepsy treated with KD had a 90\% reduction in the number of seizures, and 1 in 10 patients was seizure free during the treatment; the production of ketone bodies is directly associated with the control of seizures ${ }^{7}$.

Current literature on KD lacks information on nutritional aspects, which hinders patients and parents or guardians' understanding, prevents the complete understanding of the metabolic response to the various dietary regimens prescribed, and increases the likelihood of inadequate nutrient intake. The use of graphic representations such as the food pyramid in nutrition education enables the distribution of food into groups. It is a tool used by healthcare professionals in clinical practice aimed at eating habit changes to improve patients' overall health ${ }^{8}$. Although the KD has a distinct nutrient 
composition, with an insufficient supply of nutrients ${ }^{9}$, the use of a graphical representation can help informing patients about the variety of foods in each food group, optimize adherence to the treatment, and minimize possible side effects of nutritional deficiency, especially micronutrients.

Thus, the objective of the present study was to develop a graphical representation in the form of a food pyramid for KD for the dietary treatment in children and adolescents with refractory epilepsy.

\section{METHODS}

The diet plan was designed with typical Brazilian foods that have a macronutrient distribution range suitable for the KD. The "Manual de dietas e condutas nutricionais em pediatria" (Pediatric diet and nutritional management manual) ${ }^{10}$ was used as a reference to illustrate the foods that can be eaten including a meal plan based on the food pyramid for the age group 7-10 years.

The amount of food that counts as a serving according to the age group was calculated based on data on the nutritional composition of foods of the Tabela Brasileira de Composição de Alimentos (Taco, Brazilian Food Composition Table) ${ }^{11}$.

The food pyramid was constructed based on: the estimation of energy requirements for various age groups, macronutrient distribution, food groups, and the number of servings and respective amounts of food according to the ketogenic diet.

Portion sizes in the pyramid were defined for four age groups according to estimated energy requirement proposed by Freeman ${ }^{12}$, who determined the values of $75,68,60$, and the range $40-50 \mathrm{kcal} / \mathrm{kg}$ body weight based on the Body Mass Index (BMI)-for-age Z-score for the age groups 1-3, 4-6, 7-10, and $\geq 11$ years.

The average age of the age groups used in the calculation proposed by Freeman ${ }^{12}$ and the average weight corresponding to the $50^{\text {th }}$ percentile according to gender were used. For children aged $<10$ years, the weight was measured according to the $50^{\text {th }}$ Weight-for-Age Percentile (WAP) (WHO, 2006 and 2007); for children aged $\geq 10$ years, it was measured according to the $50^{\text {th }}$ Percentile $\mathrm{BMI}$-for-Age (PBMI/A) percentile (WHO, 2006; 2007); height was used to calculate the BMI corresponding to the $50^{\text {th }}$ Height-for-Age Percentile (HAP).

The macronutrient ratio of $4: 1$, i.e., 4 grams of fats to 1 gram of carbohydrates and proteins was used in the construction of the pyramid. Therefore, $90 \%$ of the Total Caloric Value (TCV) was derived from fats.

The protein recommendation in the $\mathrm{KD}$ ranged from 0.75 to $1.0 \mathrm{~g}$ protein/ $\mathrm{kg}$ body weight, regardless of the age group ${ }^{13}$. The amount of fat in relation to the TCV was based on the KD macronutrient ratio established (4:1), in which $90 \%$ of TCV is derived from fats, and the remaining $10 \%$ from the sum of proteins and carbohydrates. The percentage of protein in the food pyramid was previously determined, corresponding to 0.7 to $1 \mathrm{~g}$ of protein per kilogram of body weight depending on the age group. Subsequently, the percentage of carbohydrates was determined, corresponding to the difference of the percentage of carbohydrates and proteins $(10 \%)$ minus the percentage of proteins in relation to the TCV.

Protein percentage varied in the lists of food substitutes based on different factors. For age groups 1-3 years, 4-6 years, and 7-10 years, $1 \mathrm{~g}$ protein/ $\mathrm{kg}$ body weight was considered in order to maximize protein supply and prevent growth-faltering. Since the requirement for energy per kilogram of body weight of the age group 11-19 years is smaller, $0.7 \mathrm{~g}$ protein/kg body weight was adopted aiming at optimizing the supply of carbohydrate sources such as fruits and vegetables.

Considering the average energy requirements according to the different age groups, a food pyramid containing lists of food 
substitutes with average amounts (in grams) of each food serving according to the age group was designed.

The ketogenic diet food pyramid was divided into 5 food groups based on the proportion of macronutrients in each food.

Serving sizes were defined according to the food groups aiming to maintain ketone body production from fatty acid oxidation.

In order to maintain a steady rate of ketone body production throughout the day, all four meals proposed in this meal plan had the same energy proportion and macronutrient distribution, enabling a complete meal replacement.

\section{RE S U L T S}

The age groups and anthropometric characteristics of the 4 reference groups used in the development of the KD food pyramid are shown in Table 1. The total amount of fats, proteins, and carbohydrates in grams was determined based on the KD ratio of $4: 1$, as shown in Table 2. A daily food plan model was designed for the age group 7-10 years based on the distribution of macronutrients in the KD, as shown in Figure 1.

The food pyramid proposed was divided into 5 food groups (Figure 2). The serving sizes of each food group per day were determined according to the macronutrient proportion. The serving sizes varied more in the group of fats due to the fact that fatty acids are the basis of the ketogenic diet:

- $1^{\text {st }}$ tier: Fats- evaporated milk, fresh bacon, mayonnaise, and vegetable oils. MediumChain Triglycerides (MCT) can be used as substitutes for these foods -4 to 10 servings.

- $2^{\text {nd }}$ tier: Proteins - beef and pork meat, poultry, fish, eggs, and nuts, such as Brazil nuts, cashew nuts, walnuts, and peanuts -4 servings.

- $3^{\text {rd }}$ tier: Type 1 vegetables - high carb vegetables, such as pumpkin, zucchini, broccoli, carrot, chayote, collard greens, and spinach -2 servings.

- $3^{\text {rd }}$ tier: Type 2 vegetables - low carb vegetables, such as watercress, lettuce, endive, cucumber, and tomato - 2 servings.

Citrus fruits and non-citrus fruits were included in the fruit group.

Table 1. Values of $50^{\text {th }}$ percentiles adopted to calculate the average weight for each age group. São Paulo, Brazil, 2015.

\begin{tabular}{|c|c|c|c|c|c|c|c|c|c|}
\hline \multirow{2}{*}{$\begin{array}{l}\text { Age group } \\
\text { (years) }\end{array}$} & \multirow{2}{*}{$\begin{array}{l}\text { Average age } \\
\text { (years) }\end{array}$} & \multicolumn{2}{|c|}{ WAP (kg) } & \multicolumn{2}{|c|}{$\operatorname{HAP}(\mathrm{cm})$} & \multicolumn{2}{|c|}{$\mathrm{PBMI} / \mathrm{A}\left(\mathrm{kg} / \mathrm{m}^{2}\right)$} & \multirow{2}{*}{$\begin{array}{l}\text { Average height } \\
\qquad(\mathrm{cm})\end{array}$} & \multirow{2}{*}{$\begin{array}{c}\text { Average weight } \\
\qquad(\mathrm{kg})\end{array}$} \\
\hline & & $F$ & $\mathrm{M}$ & $\mathrm{F}$ & $\mathrm{M}$ & $\mathrm{F}$ & M & & \\
\hline $1-3$ & 2.0 & 11.5 & 12.2 & - & - & - & - & - & 11.9 \\
\hline $4-6$ & 5.0 & 18.2 & 18.3 & - & - & - & - & - & 18.3 \\
\hline $7-10$ & 8.5 & 26.3 & 26.5 & - & - & - & - & - & 26.4 \\
\hline $11-19$ & 15.0 & - & - & 161.7 & 169.0 & 20.2 & 19.8 & 165.3 & 54.7 \\
\hline
\end{tabular}

Note: F: Female; M: Male; WAP: Weight-for-Age Percentile; HAP: Height-for-Age Percentile; PBMI/A: Percentile Body Mass Index-for-Age.

Table 2. Total caloric value and macronutrients in a meal plan of the ketogenic diet according to age. São Paulo, Brazil, 2015.

\begin{tabular}{cccccccc}
\hline Age (years) & Weight $^{*}(\mathrm{~kg})$ & Energy $(\mathrm{kcal} / \mathrm{kg})$ & TCV $(\mathrm{kcal})$ & Fats $(\mathrm{g})$ & Proteins $(\mathrm{g})$ & Carbohydrates $(\mathrm{g}){\text { Liquids }(\mathrm{mL})^{* *}}^{*}$ \\
\hline 2.0 & 11.9 & 75.0 & 892.5 & 5.6 & 0.7 & 0.7 & 833.0 \\
5.0 & 18.3 & 68.0 & 1244.4 & 7.8 & 1.1 & 0.8 & 1281.0 \\
8.5 & 26.4 & 60.0 & 1584.0 & 9.9 & 1.7 & 0.8 & 1848.0 \\
15.0 & 54.7 & 40.0 & 2188.0 & 13.7 & 2.3 & 1.1 & 3661.0 \\
\hline
\end{tabular}

Note: *Average weight; ${ }^{* *}$ Daily fluid intake.

TCV: Total Caloric Value. 


\begin{tabular}{cc}
\hline Meal/Foods & Amount (g) \\
\hline Breakfast & 91 \\
\hline Evaporated milk shake made with & 4 \\
Papaya & 40 \\
\hline Scrambled egg with & 4 \\
Olive oil & \\
Lunch & 29 \\
\hline Ground beef with & 35 \\
\hline Fresh bacon & \\
Lettuce salad & 27 \\
Carrot puree ${ }^{*}$ with & 1 \\
\hline Canola oil &
\end{tabular}

\begin{tabular}{cc}
\hline Meal/Foods & Amount $(\mathrm{g})$ \\
\hline Mid-afternoon Snack & \\
\hline Pinneaple smoothie wih & 6 \\
\hline Evaporated milk & 91 \\
\hline Boiled egg with & 40 \\
\hline Soy oil & 4 \\
Dinner & \\
\hline Grilled chicken breast & 25 \\
\hline Stuffed tomato with & 29 \\
\hline Fresh bacon and & 35 \\
\hline Boiled broccoli with & 24 \\
Olive Oil & 6 \\
\hline
\end{tabular}

Figure 1. Example of a ketogenic diet meal plan. São Paulo, Brazil, 2015.

Note: "Prepared without milk. Example of a 4:1 ketogenic diet meal plan for a child aged 8 years and 5 months and weight of 26,4kg; total caloric value of $1584 \mathrm{kcal}$ and daily protein of $26,4 \mathrm{~g}$.

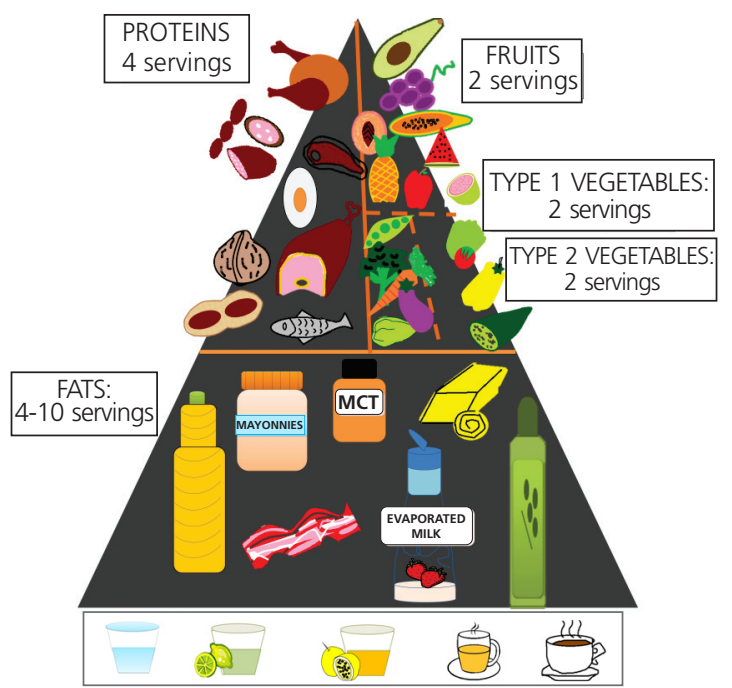

Fluid Intake control: 60 - $70 \mathrm{~mL} / \mathrm{kg}$ body weight
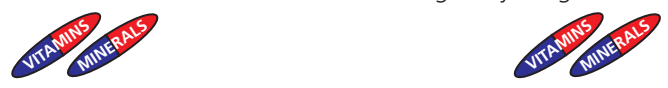

Figure 2. Food pyramid for ketogenic diet. São Paulo, Brazil, 2015.

- $3^{\text {rd }}$ tier: Fruits: citrus and non-citrus fruits, such as pineapple, guava, apple, papaya, watermelon, honeydew, and grape -2 servings.

The amount of food in each serving was defined per age group according to the portion size list (Table 3).
The amount of liquids (fluids) was also calculated according to the child weight, and the liquids allowed are: water, unsweetened tea, lemonade, passion fruit juice, and coffee, i.e., sugar-free and low-fructose beverages.

\section{DISCUSSION}

The development of this KD pyramid aimed at creating a clinical practice tool based on the maintenance of the therapeutic effect of the diet, i.e., providing $90 \%$ of the caloric intake in the form of fats.

Due to its high fat content, high fat foods were included in the first tier of the food pyramid. Among the main foods in this tier are evaporated milk, mayonnaise, and fresh bacon. These foods represent the basis of the KD since they provide an adequate fat intake and can be used in their natural form or as an ingredient in various preparations. The inclusion of these foods should not exceed the recommended amount in the diet and should respect individual preferences and regional dietary habits of patients.

Considering that $90 \%$ of the calories are in the form of fats, the remaining $10 \%$ should be evenly distributed between proteins and 
Table 3. List of food substitutes in the ketogenic diet according to age group.

1 of 2

\begin{tabular}{|c|c|c|c|c|}
\hline \multirow{2}{*}{ Foods (g or mL) } & \multicolumn{4}{|c|}{ Age group (years) } \\
\hline & $1-3$ & $4-6$ & $7-10$ & $11-19$ \\
\hline \multicolumn{5}{|l|}{ Fats } \\
\hline Evaporated milk & 58 & 78 & 91 & 140 \\
\hline Egg & 14 & 24 & 31 & 52 \\
\hline Bacon & 22 & 28 & 32 & 49 \\
\hline Vegetable oil & 1 & 2 & 4 & 1 \\
\hline \multicolumn{5}{|l|}{ Proteins } \\
\hline Beef & 10 & 18 & 29 & 41 \\
\hline Chicken & $9(2)^{*}$ & $16(3)^{*}$ & $25(5)^{*}$ & $36(7) *$ \\
\hline Pork meat & $10(1)^{*}$ & $19(2)^{*}$ & $30(3)^{*}$ & $42(4) *$ \\
\hline Boneless pork ribs & 10 & 18 & 29 & 42 \\
\hline Canned sardines in oil & 8 & 14 & 22 & 31 \\
\hline Hot dog (frankfurter) & 9 & 17 & 27 & 38 \\
\hline Mixed sausage & 8 & 15 & 24 & 34 \\
\hline Mortadella & 8 & 14 & 22 & 31 \\
\hline Fish & $9(1)^{*}$ & $16(2)^{*}$ & $26(3)^{*}$ & $37(5)^{*}$ \\
\hline Ham & 10 & 18 & 29 & 41 \\
\hline Fresh sardine & $7(1)^{*}$ & $13(1)^{*}$ & $20(2)^{*}$ & $29(3)^{*}$ \\
\hline Industrialized hamburger & $8(1)^{*}$ & $15(2)^{*}$ & $24(3)^{*}$ & $34(4)^{*}$ \\
\hline \multicolumn{5}{|l|}{ Type 1 vegetables } \\
\hline Pumpkin & 25 & 32 & 32 & 51 \\
\hline Zucchini & 32 & 40 & 40 & 64 \\
\hline Eggplant & 28 & 36 & 36 & 57 \\
\hline Broccoli & 19 & 24 & 24 & 38 \\
\hline Carrot & 21 & 27 & 27 & 43 \\
\hline Chayote & 24 & 30 & 30 & 48 \\
\hline Cauliflower & 22 & 28 & 28 & 45 \\
\hline Collard greens & 17 & 22 & 22 & 35 \\
\hline Spinach & 27 & 34 & 34 & 54 \\
\hline Turnip & 35 & 44 & 44 & 71 \\
\hline Okra & 17 & 22 & 22 & 35 \\
\hline Cabbage & 27 & 33 & 33 & 53 \\
\hline Green bean & 24 & 30 & 30 & 48 \\
\hline hearts of palm (Jar or can) & 39 & 49 & 49 & 78 \\
\hline \multicolumn{5}{|l|}{ Type 2 vegetables } \\
\hline Chinese cabbage & 17 & 20 & 22 & 20 \\
\hline Watercress & 20 & 24 & 25 & 23 \\
\hline Lettuce & 29 & 35 & 37 & 34 \\
\hline Wild chicory & 21 & 25 & 27 & 25 \\
\hline Common chicory & 19 & 23 & 25 & 23 \\
\hline Endive & 21 & 25 & 27 & 25 \\
\hline Green olive & 28 & 34 & 36 & 33 \\
\hline Arugula & 20 & 24 & 25 & 23 \\
\hline Cucumber & 30 & 36 & 38 & 35 \\
\hline Bell pepper & 15 & 18 & 19 & 17 \\
\hline Radish & 21 & 25 & 26 & 24 \\
\hline Tomato & 23 & 27 & 29 & 26 \\
\hline \multicolumn{5}{|l|}{ Fruits } \\
\hline Pineapple & 17 & 16 & 6 & 9 \\
\hline Avocado & 14 & 13 & 5 & 7 \\
\hline Fresh plum & 10 & 9 & 3 & 5 \\
\hline Persimmon & 5 & 5 & 2 & 3 \\
\hline Starfruit & 11 & 10 & 4 & 6 \\
\hline
\end{tabular}


Table 3. List of food substitutes in the ketogenic diet according to age group.

\begin{tabular}{|c|c|c|c|c|}
\hline \multirow{2}{*}{ Foods (g or mL) } & \multicolumn{4}{|c|}{ Age group (years) } \\
\hline & $1-3$ & $4-6$ & $7-10$ & $11-19$ \\
\hline \multicolumn{5}{|l|}{ Fruits } \\
\hline Ripe fig & 6 & 6 & 2 & 3 \\
\hline Guava & 6 & 5 & 2 & 3 \\
\hline Kiwi & 7 & 7 & 2 & 4 \\
\hline Apple & 7 & 6 & 2 & 3 \\
\hline Papaya & 12 & 11 & 4 & 6 \\
\hline Mango & 7 & 6 & 2 & 3 \\
\hline Watermelon & 18 & 17 & 6 & 9 \\
\hline Honeydew & 16 & 14 & 5 & 8 \\
\hline Mandarin & 9 & 8 & 3 & 4 \\
\hline Strawberry & 11 & 10 & 4 & 6 \\
\hline Pear & 7 & 7 & 2 & 4 \\
\hline Peach & 10 & 10 & 3 & 5 \\
\hline Grape & 6 & 6 & 2 & 3 \\
\hline
\end{tabular}

Note: ${ }^{*}$ Amount of oil added in $\mathrm{mL}$.

carbohydrates. The importance of macronutrient intake control is directly related to the mechanisms of action of the KD. According to McNally \& Hartman ${ }^{14}$, these mechanisms are associated with the ketone body production from fatty acid oxidation.

Despite the clinical efficacy of the $K D$, its high fat content has been associated with adverse effects, such as an increase in Low Density Lipoprotein (LDL) and Triglycerides (TG $)^{9,15,16}$, which could lead to an increased cardiometabolic risk.

In addition to containing fats, evaporated milk, fresh bacon, and mayonnaise also have low levels of carbohydrates and proteins. Thus, the intake of these foods must be controlled during the dietary treatment. Vegetable oils and MCT, which are also included in the first tier of the food pyramid, can be used to complement fat intake without compromising the intake of other foods that are sources of carbohydrates and proteins such as meats, fruits, and vegetables, which were included in the second and third tier of the food pyramid.

The ketogenic diet allows the use of most vegetable oils and complementation of fat intake. However, considering that dyslipidemia is one of the major adverse effects of this treatment, the qualitative aspects associated with the fatty acid composition should be taken into consideration in this therapeutic approach.

In the second tier of the food pyramid, there are foods that are sources of proteins. Among the main foods included in this tier are eggs and meats: beef, pork, poultry, and fish. Some ultra-processed meats such as hot dog (frankfurter), sausage, mortadella, ham, hamburger, and canned sardines were also included in this tier due to their high protein content. However, their intake should be limited because they are high levels in saturated fats and sodium.

The inclusion of some nuts such as, Brazil nuts, cashew nuts, walnuts, and peanuts in the protein group was also prioritized because these foods contain adequate levels of proteins and a fat that can produce beneficial effects on the lipid metabolism in patients treated with ketogenic diet. These foods can be eaten at breakfast and snacks as they do not require prior preparation and are easy to consume. The inclusion of meat, eggs, and oil in the meal plan of patients under treatment with KD should reflect an adequate amino acid composition of high biological value. 
Vining et al. ${ }^{17}$ found that epileptic patients had decreased weight Z-scores after 3 months of treatment with KD, which led to a small decrease in the height Z-scores after 6 months of dietary intervention. Liu et al. ${ }^{9}$ reported that 14 children received classical KD and 11 received (MCT) ketogenic diet did not have statistically significant increases in height/age percentiles after 4 months of treatment with $\mathrm{KD}$ and a decrease in weight/ age percentiles by 10 percentiles. These results confirmed the importance of adequate monitoring of calorie and protein intake in order to promote health, reduce morbidity, and prevent weight and height deficits.

In addition to the adverse effects due to lipid metabolism changes and possible impacts on growth rate, KD can also cause vitamin and mineral deficiency due to the low supply of foods that are sources of fruits and vegetables. The variety of foods illustrated in the food pyramid enables to emphasize the qualitative aspects of the diet focusing on reducing the micronutrient deficiency intrinsic to the KD.

In 2003, Liu et al. ${ }^{9}$ compared micronutrient intake from the KD diet and vitamin supplements in patients with refractory epilepsy. The authors found that after 4 months of dietary intervention, the nutrient intakes and supplementation in these patients met the Dietary Reference Intakes (DRI) recommendations, except for phosphorus and folate. Despite these results, the authors concluded that if the patients had not received multivitamin and mineral supplementation, the KD would not have supplied enough most of the micronutrients analyzed.

More recent studies have reported that micronutrient deficiency can be partially controlled with multivitamin and mineral supplements, especially calcium, iron, selenium, zinc, and vitamin $D^{3}$. Therefore, vitamin and mineral supplements were included at the bottom of the food pyramid, and they should be prescribed based on individual clinical status and nutritional needs of patients.
The recommended servings for the food groups can be divided into 4 meals of same caloric value and the same macronutrient proportion. All meals should include all food groups in order to maintain this proportion and maximize nutrient supply.

The amount of food that counts as a serving is individualized and depends on factors such as age, weight, and patient nutritional status. In the first tier, 4-10 servings of food sources of fats are recommended. Considering the number of 4 meals per day and that each one provides 1 serving of food that is source of fats (evaporated milk, bacon, or mayonnaise), the other servings can provide vegetable oils or MCT. The maximum variation of 10 servings may be possible depending on the nutritional composition of the meat used for lunch and dinner. If meats (fish, poultry, and pork) are included, vegetable oils or MCT should be added to complement the supply of fats and maintain the required macronutrient proportion to guarantee beneficial effects of the ketogenic diet.

The consumption of 4 servings of the foods in the second tier (proteins) is recommended in order to guarantee the supply of foods from all food groups at every meal and thus maintain an even macronutrient distribution across all meals.

In the third tier, the consumption of 2 servings of foods from each food group is recommended aiming at the supply of 1 serving of type 1 vegetables and 1 serving of type 2 vegetables per meal and 1 serving of foods from the fruit group at breakfast and mid-afternoon snack.

The distribution of all servings of same caloric value and macronutrient proportion across the 4 meals aimed at optimizing the amount of food supplied and facilitate the preparation of the meals by the parents and/or guardians to improve treatment adherence.

The foods included in the pyramid are illustrative; therefore other foods can be included if they have a macronutrient proportion suitable for the KD and the amount of servings is 
calculated based on the individual needs of patients. Considering these aspects, the dietitian should select the foods in the diet based on preferences and regional dietary habits of patients and provide guidance concerning possible food and/or recipe combinations in order to make the meals more palatable, improving adherence to treatment.

Patients should receive proper nutritional guidance by emphasizing the need for the adequate consumption of all food groups and explaining that these foods must be weighed before their preparation to ensure adequate proportion and supply of macronutrients that are essential to guarantee the therapeutic effects of ketogenic diet.

The benefits of the KD in the treatment of refractory epilepsy have been well documented in the literature. Several studies have reported a reduction $>50 \%$ of seizures in at least half of children and adolescents subjected to this treatment ${ }^{18,19}$. These clinical benefits go beyond seizure control since many children and adolescents can benefit from reducing the use of anti-epileptic drugs (number and dose of drugs)20. These effects are considered of great clinical significance since seizures are associated with brain damage and have a negative impact on neurobiological and cognitive aspects. Moreover, it is worth mentioning that anti-epileptic drugs are associated with more subtle side effects such as gastrointestinal disorders and stronger side effects such as reduced visual acuity ${ }^{21}$.

\section{CONCLUSION}

The ketogenic diet food pyramid proposed is innovative and clinically relevant because it can help healthcare professionals to design a dietary therapy with ketogenic diet. Furthermore, it can facilitate the development a meal plan based on the clinical status and nutritional needs of each patient optimizing treatment adherence. Therefore we conclude that the adequate use of the KD food pyramid can guarantee the beneficial effects of the diet and contribute to adequate growth and nutritional support according to the individual needs of children and adolescents aged 1-19 years.

\section{A CKNOLEDGEMENTS}

Dr. Leticia Pereira de Brito Sampaio, Neuropediatrician at the Ketogenic Diet clinic of the Children's Institute of the Public Hospital of São Paulo for sharing her knowledge and professional experience. We are also grateful for the financial support provided by Fundação de Amparo à Pesquisa do Estado de São Paulo.

\section{CONTRIBUTORS}

MB PRUDENCIO and PA LIMA carried out the writing, analysis and review of the manuscript; contributed to the methodological elaboration, and pyramid design. MB PRUDENCIO was responsible to calculate and to prepare the food portion list. MCP FREITAS and DK MURAKAMI carried out an analysis and review of the manuscript, and contributed to the methodological approaches and pyramid design. FC CARTOLANO contributed to the analysis and review of the manuscript, methodological approaches and pyramid design and prepares the food portion list. NRT DAMASCENO was responsible for manuscript design, methodological approaches, pyramid design and critical review of the manuscript.

\section{REFERE NCES}

1. Shimada T, Takemyia T, Sugiura H, Yamagata K. The Role of Inflammatory Mediators in the Pathogenesis of Epilepsy. Pediatr Gastroenterol Hepatol Nutr. 2014;15:74-8.

2. Armeno M, Caraballo R, Vaccarezza M, Alberti MJ, Ríos V, Galicchio S, et al. Consenso nacional sobre dieta cetogénica. Rev Neurol. 2014;59(5):213-23.

3. Kossoff EH, Wang HS. Dietary therapies for epilepsy. Biomed J. 2013;36(1):2-8.

4. Kossoff EH, Zupec-Kania BA, Amark PE, BallabanGil KR, Christina Bergqvist AG, Blackford R, et al. Optimal clinical management of children receiving the ketogenic diet: Recommendations of the International Ketogenic Diet Study Group. Epilepsia. 2009;50(2):304-17. 
5. Kim DW, Kang HC, Park jung C, Kim HD. Benefits of the non fasting ketogenic diet compared with the initial fasting ketogenic diet. Pediatrics. 2004;114(6):1627-30.

6. Lee PR, Kossoff EH. Dietary treatments for epilepsy: Management guidelines for the general practitioner. Epilepsy Behav. 2011;21(2):115-21.

7. Gano LB, Patel M, Rho JM. Ketogenic diets, mitochondria and neurological diseases. J Lipid Res. 2014;55(11):2211-28.

8. Philippi ST, Latterza AR, Cruz ATR, Ribeiro LC. Pirâmide alimentar adaptada: guia para escolha dos alimentos. Rev Nutr. 1999;12(1):65-80.

9. Liu Y-MC, Williams S, Basualdo-Hammond C, Stephens D, Curtis R. A prospective study: Growth and nutritional status of children treated with the ketogenic diet. JADA. 2003;103(6):707-12.

10. Murakami D, Lima PA. In: Silva APA, Nascimento AG, Zamberlan P. Manual de dietas e condutas nutricionais em pediatria. $2^{a}$ ed. São Paulo: Atheneu; 2014. p.2017-14.

11. Universidade Estadual de Campinas. Tabela Brasileira de Composição de Alimentos (Taco). $4^{a}$ ed. Campinas: Unicamp; 2011.

12. Freeman JM, Kelly MT, Freeman JB. The epilepsy diet treatment: An introduction to the ketogenic diet. New York: Demos; 1994.

13. Nonino-Borges CB, Bustamante VCT, Rabito El, Inuzuka LM, Sakamoto AC, Marchini JS. Dieta cetogênica no tratamento de epilepsias farmacorresistentes. Rev Nutr. 2004;17(4):515-21. https://doi. org/10.1590/S1415-52732004000400011

14. McNally MA, Hartman AL. Ketone bodies in epilepsy. J Neurochemist. 2012;121(1):28-35. https:// doi.org/10.1590/S1415-52732004000400011
15. Kwiterovich PO, Vining EPG, Pyzik P, Skolasky R, Freeman JM. Effect of a high-fat ketogenic diet on plasma levels of lipids, lipoproteins, and apolipoproteins in children. JAMA. 2003;290(7):912-20.

16. Nizamuddin J, Turner Z, Rubenstein JE, Pyzik PL, Kossoff EH. Management and risk factors for dyslipidemia with the ketogenic diet. J Child Neurol. 2008;23(7):758-61.

17. Vining EPG, Pyzik P, McGrogan J, Hladky H, Anand A, Kriegler $S$, et al. Growth of children on the ketogenic diet. Dev Med Child Neurol. 2002;44(12):796-802.

18. Porta N, Vallée L, Boutry E, Fontaine M, Dessein AF, Joriot $\mathrm{S}$, et al. Comparison of seizure reduction and serum fatty acid levels after receiving the ketogenic and modified Atkins diet. Seizure. 2009;18(5):359-64.

19. Kinderen R, Lambrechts $D$, Postulart $D$, Kessels $A$, Hendriksen J, Aldenkamp A, et al. Research into the (Cost-) effectiveness of the ketogenic diet among children and adolescents with intractable epilepsy: Design of a randomized controlled trial. BMC Neurol. 2011;11(1):10.

20. Kossoff EH, Pyzik PL, McGrogan JR, Rubenstein JE. The impact of early versus late anticonvulsant reduction after ketogenic diet initiation. Epilepsy Behav. 2004;5(4):499-502.

21. Rocha GP, Batista BH, Nunes ML. Orientações ao pediatra sobre o manejo das drogas psicoativas e antiepilépticas. J Pediat. 2004;80(2):45-55.

Received: September 11, 2015 Final version: August 5, 2016 Approved: October 13, 2016 